\title{
The Role of GPI-anchored PrPC in Mediating the Neurotoxic Effect of Scrapie Prions in Neurons
}

\section{Helois E. Radford and Giovanna R. Mallucci*}

In vivo models of Neurotoxicity Group, MRC Toxicology Unit, Hodgkin Building, University of Leicester, Lancaster Road, Leicester, LE1 9EH, UK

\begin{abstract}
There are two central phenomena in prion disease: prion replication and prion neurotoxicity. Underlying them both is the conversion of a host-encoded ubiquitously expressed protein, prion protein $\left(\mathrm{PrPC}^{\mathrm{C}}\right)$, into a partially-protease resistant isoform, $\mathrm{PrPSc}^{\mathrm{S}}$, which accumulates in the brain. $\mathrm{PrPSc}^{\mathrm{S}}$ is associated with both pathology and infectivity (Prusiner, 1991). In the absence of $\mathrm{PrP}^{\mathrm{C}}, \mathrm{PrP}^{\mathrm{Sc}}$ cannot be generated and PrP-null mice do not propagate infectivity or develop pathology on infection with scrapie (Bueler et al., 1993; Manson et al., 1994; Sailer et al., 1994). However, while $\mathrm{PrP}^{\mathrm{C}}$ expression is fundamental to both prion infectivity and neurodegeneration, the uncoupling of these processes is a growing concept in the field. This dissociation is evident in subclinical states of prion infection (Hill et al., 2000), where $\mathrm{PrP}^{\mathrm{Sc}}$ levels are high in the absence of disease, and in transgenic mice experiments, where, despite extraneuronal PrPSc accumulation, even in very high amounts, there is no neurotoxicity (Chesebro et al., 2005; Mallucci et al., 2003). Both these models have further implications. Thus depleting $\mathrm{PrP}^{\mathrm{C}}$ from neurons (but not glia) of prion-infected mice prevents clinical disease (Mallucci et al., 2003), and detaching it from the surface of cells by removing its anchor does the same (Chesebro et al., 2005). The uncoupling toxicity and infectivity has implications for the nature of the neurotoxic species; these mouse models suggest that the site for the generation of this species is intra-neuronal. This review considers the role of neuronal surface-expressed $\mathrm{PrPC}^{\mathrm{C}}$ in mediating toxicity in prion infection, and the dissociation of this from the deposition of $\mathrm{PrP}^{\mathrm{Sc}}$.
\end{abstract}

\section{Introduction: concepts of neurotoxicity in prion disease}

Prion diseases, or transmissible spongiform encephalopathies, are fatal neurodegenerative conditions of humans and animals, which are transmissible within or between mammalian species. They are associated with the accumulation in the brain of an abnormal, partially proteaseresistant, isoform of host-encoded prion protein $(\mathrm{PrP})$. The normal cellular isoform, $\mathrm{PrP}^{\mathrm{C}}$, is widely expressed but found at the highest level in the CNS as a glycosylated, glycosylphosphatidylinositol (GPI) anchored cell-surface protein (Caughey et al., 1989; Stahl et al., 1987).

The disease-related isoform ( $\mathrm{PrPSc}^{\mathrm{Sc}}$ is derived from $\mathrm{PrPC}^{\mathrm{C}}$ by a post-translational process that involves conformational change and aggregation. $\mathrm{PrP}^{\mathrm{C}}$ is rich in $\alpha$-helical structure while $\mathrm{PrP}^{\mathrm{Sc}}$, which is found as insoluble

\section{*grm7@le.ac.uk}

aggregates, appears to be predominantly composed of ß-sheet structure. Many studies support the 'protein-only' hypothesis (Griffith, 1967; Prusiner, 1982) namely that an abnormal PrP isoform is the principal, and possibly the sole, constituent of the transmissible agent or prion. PrPSc is thought to act as a conformational template, recruiting $\mathrm{PrP}^{\mathrm{C}}$ to form further $\mathrm{PrP}^{\mathrm{Sc}}$. Prion propagation may involve recruitment of an alternately folded form of $\mathrm{PrPC}^{\mathrm{C}}$, into $\mathrm{PrPSc}$ aggregates, the process being driven thermodynamically by intermolecular interactions (Jackson et al., 1999).

However, the cause of neuronal death in prion disease remains unclear, in particular, the role played by $\mathrm{PrPSc}$. The idea that neurodegeneration follows from direct toxicity of $\mathrm{PrP}^{\mathrm{Sc}}$ and/or prions (Prusiner, 1991) has been increasingly challenged. $\mathrm{PrP}^{\mathrm{Sc}}$ does not seem to have direct toxic effects on neurons in vivo, despite in vitro evidence for both full length PrPSc (Muller et al., 1993) and shorter fragments (Forloni et al., 1993) being toxic to primary cultured neurons. There are several inherited prion diseases in which $\mathrm{PrPSc}$ is not detected in significant amounts despite fatal clinical disease (Collinge et al., 1995; Medori et al., 1992; Tateishi et al., 1992), and often there is poor correlation between PrPSc deposits and clinical signs or neuronal loss (Collinge et al., 1995; Hsiao et al., 1990; Medori et al., 1992). Most tested potential therapeutic agents that target the accumulation of $\mathrm{PrP}^{\mathrm{Sc}}$ have shown disappointing therapeutic benefit in prion infected animals. At best, they prolong incubation periods, even if given before, or at the time of, peripheral infection, but they do not prevent neurodegeneration and death (see (Mallucci and Collinge, 2005; Trevitt and Collinge, 2006) for reviews). What is clear is that host $\mathrm{PrP}^{\mathrm{C}}$ is absolutely necessary for prion-induced neurotoxicity as well as for $\mathrm{PrP}^{\mathrm{Sc}}$ production. This is seen in the resistance of PrP-null mice to prion neurotoxicity (Brandner et al., 1996; Bueler et al., 1993; Manson et al., 1994; Sailer et al., 1994), and in the rescue of neurons from degeneration when $\mathrm{PrPC}^{\mathrm{C}}$ is 'removed' from them, preventing ongoing neuronal prion replication (Mallucci et al., 2003; Mallucci et al., 2007; White et al., 2008) (see below). But even where $\operatorname{PrP}^{\mathrm{C}}$ is present to support prion replication and mediate the neurotoxicity of $\mathrm{PrP}^{\mathrm{Sc}}$, PrPSc accumulation and toxicity can be uncoupled. This is seen in subclinical forms of prion infection in which animals can harbour high levels of infectivity, and $\mathrm{PrPSc}$, without clinical disease (Hill and Collinge, 2003; Hill et al., 2000; Race et al., 2001), or where prion replication is extraneuronal (Chesebro et al., 2005; Mallucci et al., 2003). In mice where neuronal $\mathrm{PrPC}$ is deleted during the course of infection, but glial replication of $\mathrm{PrP}^{\mathrm{Sc}}$ continues (Mallucci et al., 2003), and in mice in which the GPI-anchor is removed, detaching PrP from the cell surface but allowing replication to occur away from the cell bodies and processes (Chesebro et al., 2005), neurotoxicity does not occur despite extensive PrPSc accumulation.

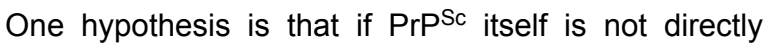
neurotoxic, it is the depletion of $\mathrm{PrPC}^{\mathrm{C}}$ during prion replication that damages cells. The normal function of 
A

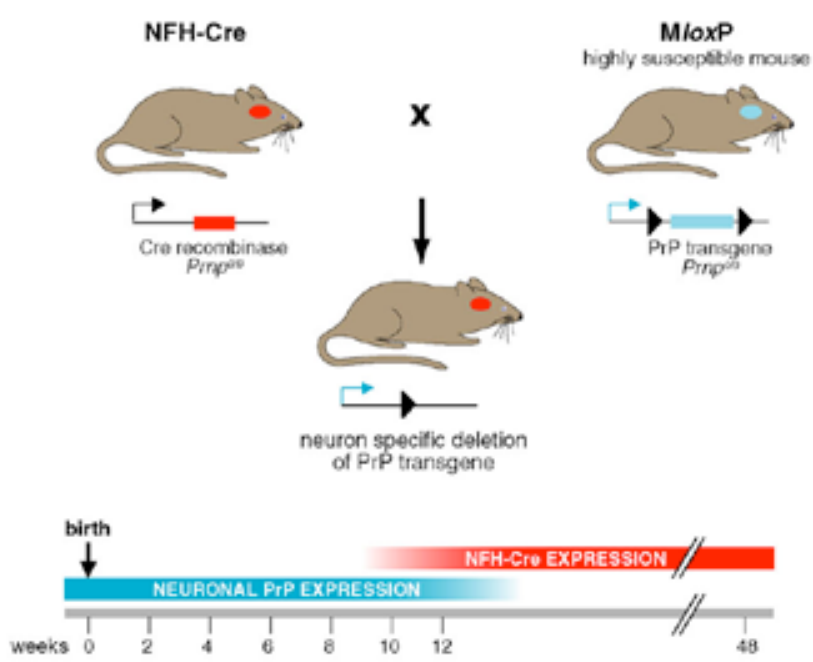

B

Mloxp
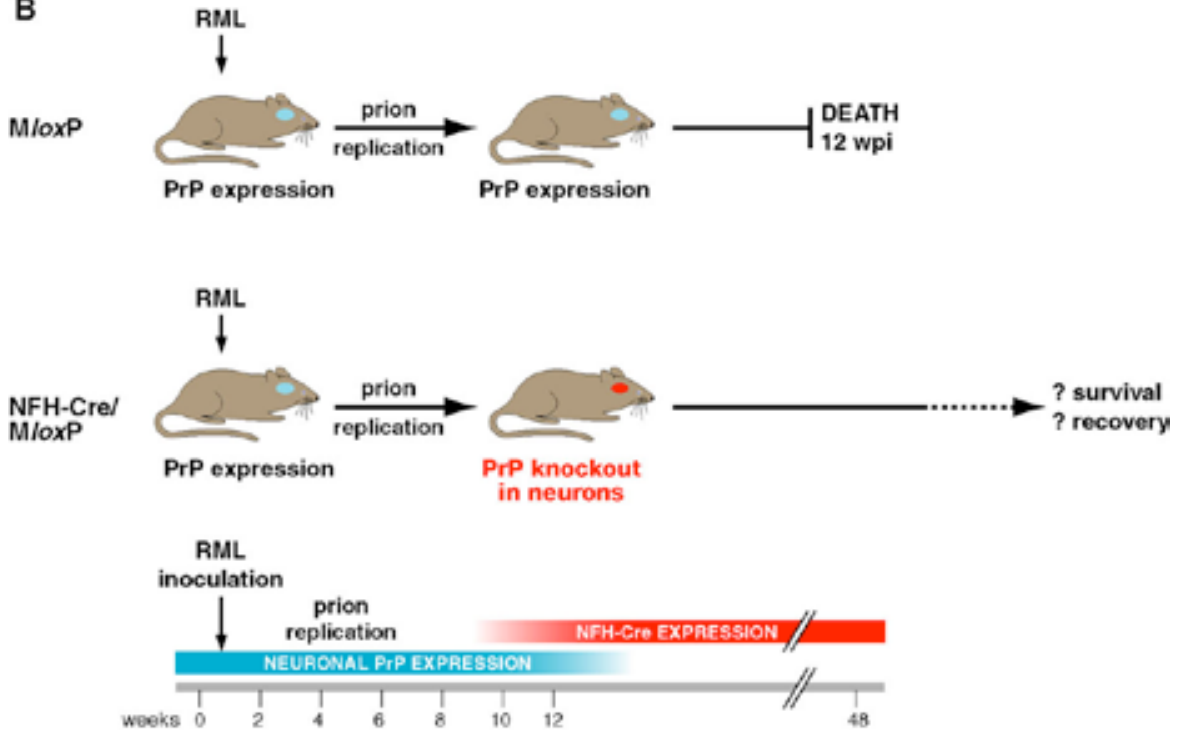

Figure 1. Adult onset $\mathrm{PrP}^{\mathrm{C}}$ knockout in neurons by Cre-mediated recombination in mice; a model for studying neurotoxicity in prion disease A. NFH-Cre mice express Cre recombinase in neurons at $\sim 9$ weeks of age which deletes PrP transgenes from MloxP mice. B. The model is used to study the effects of neuronal $\mathrm{PrP}^{\mathrm{C}}$ knockout during RML prion infection. Both $\mathrm{NFH}$ Cre/MloxP and MloxP control mice replicate prions for 8 weeks, after which double transgenic animals lose neuronal PrP expression.

$\mathrm{PrP}^{\mathrm{C}}$ is incompletely understood, and there is evidence that it may be neuroprotective (see review by Martins et al, this issue) and that aberrant trafficking or topology can be neurotoxic (Hegde et al., 1998; Hegde and Rane, 2003; Ma and Lindquist, 2002) (reviewed by Miesbauer et al; this issue). Yet the lack of neurodegeneration in either acquired (Mallucci et al., 2002), or embryonic (Bueler et al., 1993; Manson et al., 1994; Sailer et al., 1994), PrP knockout mice and in mice lacking correctly anchored (and hence functional) PrP (Chesebro et al., 2005), argues against this.

The uncoupling of $\mathrm{PrP}^{\mathrm{Sc}}$ and neurotoxicity indicates that it is not the aggregated, protease resistant core of the molecule that is toxic to cells. But this begs the question of what the toxic species is? The central role of $\mathrm{PrP}^{\mathrm{C}}$ conversion in the process suggests the generation of a toxic intermediate species, which may never aggregate, or whose toxicity is in any case independent of eventual aggregation. The possibility that this species may not only be transient and soluble, but needs to be generated within neurons is discussed below along with alternative explanations.

Prion neurotoxicity: a critical role for neuronal expression and surface anchoring of $\mathrm{PrP}^{\mathrm{C}}$ ?

The demonstration of recovery of early degenerative prion pathology and behavioral and neurophysiological deficits in mice in which neuronal $\mathrm{PrP}^{\mathrm{C}}$ was depleted during infection, gives potentially important insights into possible mechanisms of prion neurotoxicity. The evidence comes from use of a mouse model in which $\mathrm{PrP}^{\mathrm{C}}$ is depleted from neurons in the 
A

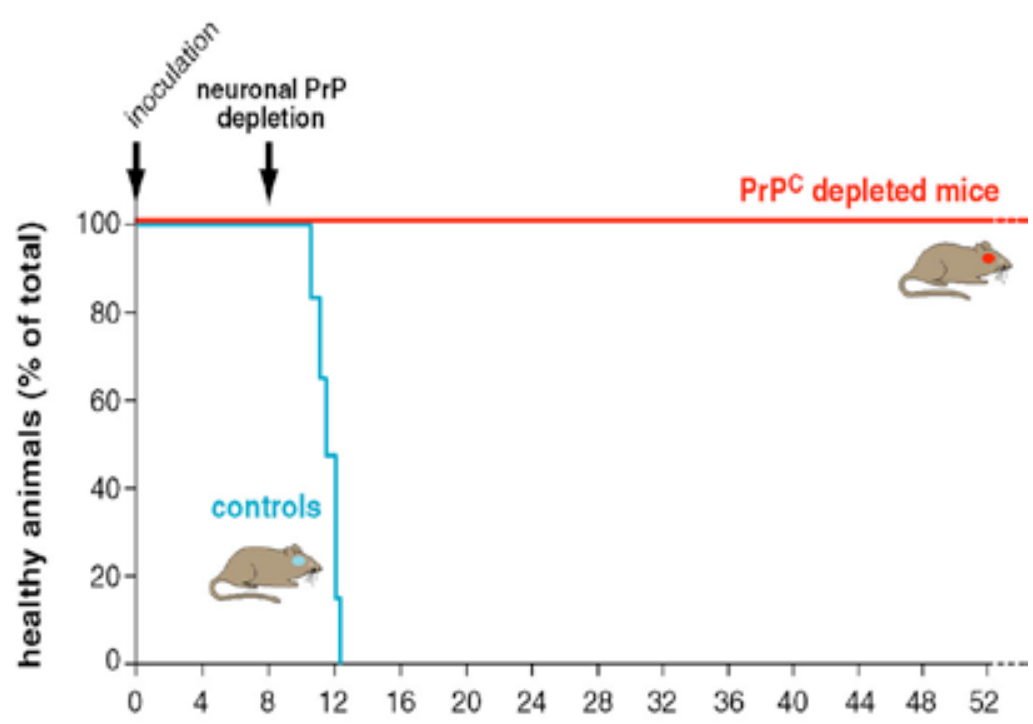

B
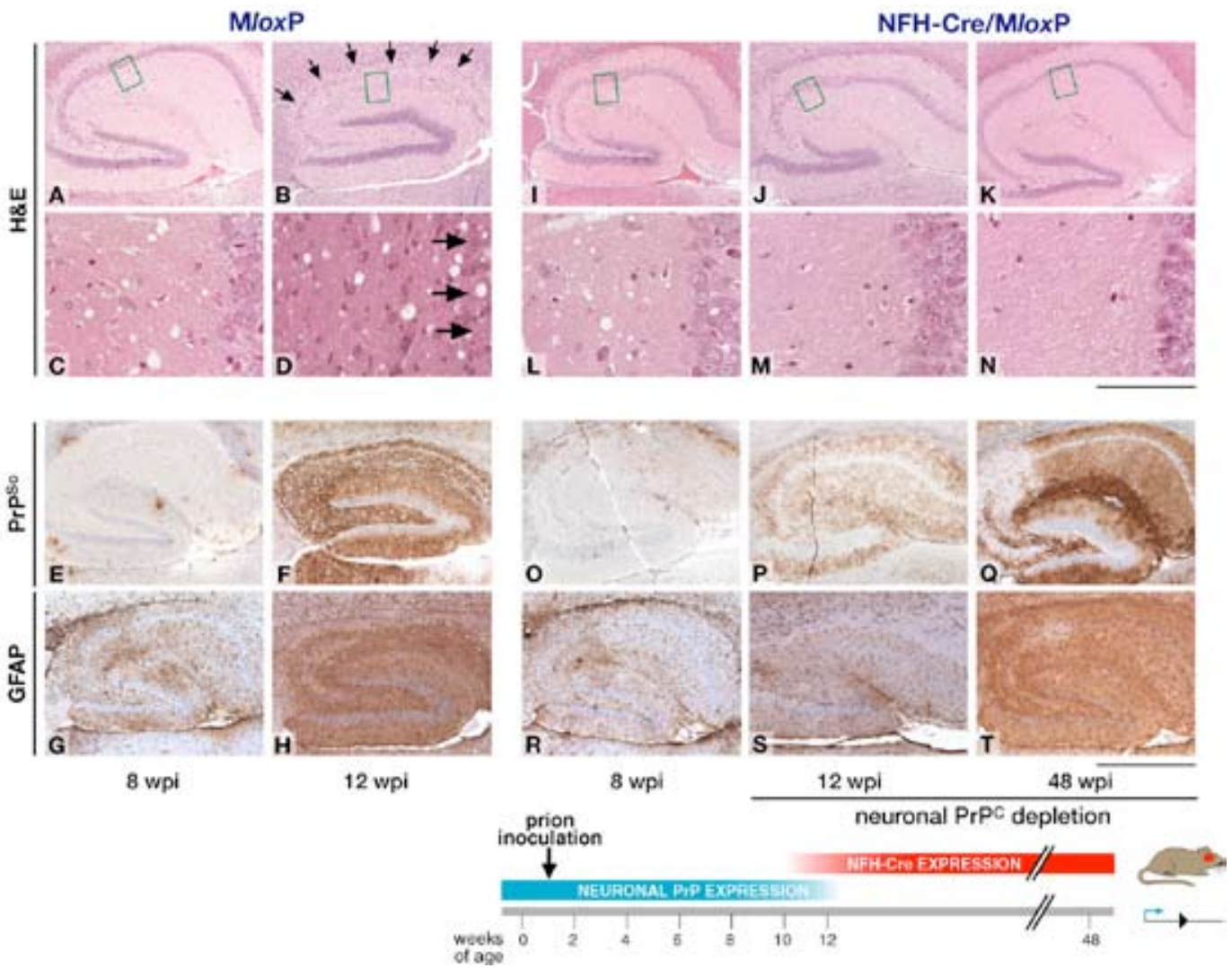

Figure 2. Scrapie-infected NFH-Cre/tg37 mice survive long term after Cre-mediated PrPC depletion and early pathology reverses despite ongoing extra-neuronal PrPSc accumulation. A. Kaplan-Meier survival plot of RML scrapie prion-inoculated mice. All control MloxP mice (blue curve) succumbed to scrapie within 12 wpi $(n=6)$. No animals with Cre-mediated PrPC depletion at $8 \mathrm{wpi}$ (red line) succumbed to scrapie or show any clinical signs of disease by 52 wpi $(n=6)$. The timing of inoculation and the onset of Cre-mediated $\operatorname{PrP}^{\mathrm{C}}$ depletion 8 weeks into the course of infection, are indicated (arrows). B. Fixed sections of brains from scrapie-infected MloxP and NFH-Cre/M/oxP mice, stained with haematoxylin and eosin (H\&E), and immunostained for GFAP and PrPSc detection. Neuronal PrP depletion by Cre-mediated recombination in NFH-Cre/ MloxP mice from 8 wpi is indicated. There is severe neuronal loss of hippocampal regions CA1-3 (arrows) (B,D) and indeed shrinkage of the entire hippocampus $(B)$ in clinically sick MloxP mice, but no neuronal loss in prion-infected mice with Cremediated $\operatorname{PrP}^{C}$ depletion (I-K, L-N) up to 48 wpi. Early spongiform change is seen at 8 wpi in all mice $(C, L)$, which recovers in scrapie-infected animals after Cre-mediated recombination $(M, N)$. PrPsc accumulation $(P, Q)$ and gliosis $(S, T)$ continues in $\mathrm{NFH}-\mathrm{Cre} / \mathrm{M} /$ oxP mice after Cre-mediated PrPC depletion (R-T). Scale bar represents $320 \mu \mathrm{m}$ in all panels, except for panels C,D and L,M,N where it represents $80 \mu \mathrm{m}$. 
adult animal, after the nervous system is fully developed (Mallucci et al., 2002). Infecting these mice before knockout of PrP occurred allowed the effects of depleting neuronal $\mathrm{PrP}^{\mathrm{C}}$ during the course of prion disease to be studied. In this system, PrP is expressed from 'floxed' transgenes (M/oxP) and is deleted by expression of the enzyme Cre recombinase in neurons (from the NFH-Cre transgenes), see Figure 1. In contrast to PrP-null mice where deletion is embryonic, and global, the knockout of PrP here is acquired (at 9 weeks of age). Further, the knockout is neuron-specific, as the NFH promoter is expressed only in neurons. Mice were infected with prions at one week of age, 8 weeks before the onset of transgene mediated $\operatorname{PrP}$ depletion, allowing prion infection to develop over this time. By the time PrP depletion occurred, prion neuropathological change was established, with early spongiform change, astrocytosis and $\mathrm{PrPSc}^{\mathrm{S}}$ deposition. Control MloxP animals without transgene meditated depletion at this stage of disease progressed to full prion neurodegeneration and death within 4 weeks. But animals in which $\operatorname{PrP}^{\mathrm{C}}$ was knocked out at this time point survived, asymptomatic, long term (Figure $2 \mathrm{~A}$ ) and showed reversal of early spongiform change (Figure $2 B$, panels $L, M, N$ ). The animals were effectively clinically cured (Mallucci et al., 2003). This occurred despite the continued accumulation of extra-neuronal $\mathrm{PrPSc}^{\mathrm{Sc}}$ over time to levels observed in terminally sick wild-type animals (Figure $2 \mathrm{~B}$, panel $\mathrm{Q}$ ). This extra-neuronal conversion of $\mathrm{PrP}^{\mathrm{C}}$ to $\mathrm{PrP}^{\mathrm{Sc}}$ was not toxic to neurons, however. By 48 weeks post-infection, the animals had accumulated levels of PrPSc (and prion titres) as high as those seen in end-stage clinical prion disease in control mice, but no symptoms or neuronal loss were observed, suggesting that it is the occurrence of prion conversion within neurons that is pathogenic. Here, neurotoxicity and $\mathrm{PrP}^{\mathrm{Sc}}$ accumulation are unequivocally uncoupled, and the data validated approaches in prion disease therapeutics targeting PrPC; which was further confirmed using RNAi against PrP in prion infection (White et al., 2008). Further analysis of this model led to questions about the cell types involved in prion neurotoxicity, the nature of the toxic species and the timing of treatment in prion disease.

So does prion replication have to be intra-neuronal to be toxic? Certainly, this model supports this concept. Different cell types appear to be important in prion disease infectivity and pathogenesis. Both neurons and astrocytes propagate prions, and astrocytes may be the earliest sites of PrPSc accumulation (Diedrich et al., 1991). But astrocytic replication is not essential for prion neurotoxicity as expressing $\operatorname{PrP}$ in neurons alone in transgenic mice is sufficient to render the animals susceptible to prion disease (Race et al., 1995). Similarly, the data discussed above, where neuronal PrPC depletion is protective against neurotoxicity, supports the argument that prion replication must be intra-neuronal to be toxic. Yet a mouse model in which PrPC expression was directed towards astrocytes using the GFAP promoter to drive hamster $\operatorname{PrP}(\mathrm{HaPrP})$ expression also restored susceptibility to hamster scrapie prions in these mice (Raeber et al., 1997). These mice showed prion pathological changes (spongiform changes and astrogliosis), but no neuronal loss. Electron microscopy showed that neurons were primarily damaged and astrocytes appeared to not show any degenerative changes, although the $\mathrm{HaPrPSc}$ mainly colocalised to astrocytes (Jeffrey et al., 2004). How does this reconcile with resistance of mice with acquired neuronal knockout of PrP to astrocyte PrPSc mediated neurotoxicity? The two models differ significantly and are not directly comparable for a number of reasons, including having been generated on different genetic backgrounds, expressing different species of PrP under different promoters and infection with different scrapie strains. GFAP-PrP mice over-express hamster $\mathrm{PrP}^{\mathrm{C}}$ in astrocytes due to exponential induction of the GFAP promoter during infection, while in MloxP mice there is low-level astrocytic expression of mouse $\mathrm{PrP}^{\mathrm{C}}$ expression under its own promoter. Further, $263 \mathrm{~K}$ scrapie used to infect the GFAP-PrP mice produces very little neuronal loss, in contrast to the severe neurodegeneration induced by RML infection of MloxP mice. Further, it is increasingly clear that GFAP promoter activity is not entirely restricted to astrocytes. It is widely expressed in developing cerebellar interneurons, contributing up to $30 \%$ of the final population of these cells (Silbereis et al., 2009) and is also widely expressed throughout life in neural stem cells in the adult forebrain in the subventricular zone (Morshead et al., 2003). Recent evidence from genetic fate mapping of postnatal GFAP positive cells reveals that they seed the postnatal brain with neural progenitors that in turn give rise to their mature neuronal progeny throughout the CNS, including the cerebral cortex (Ganat et al., 2006). Thus it is likely that the GFAP-PrP mice are indeed expressing $\mathrm{PrP}$ in a sufficient number of neurons, to restore susceptibility of these mice to prion neurotoxicity.

While this mouse model makes a strong case for prion neurotoxicity hinging on the intra-neuronal conversion of $\mathrm{PrP}^{\mathrm{C}}$ to $\mathrm{PrPSc}^{\mathrm{Sc}}$, it is also possible that in fact this need for neuronal replication actually reflects a kinetic effect rather than cell specificity. Thus the effect of gene dosage, and hence levels of expression, of PrP are known to correlate inversely with prion incubation times, despite extensive build-up of $\mathrm{PrPSc}$ and prion titre (Bueler et al., 1994; Weissmann et al., 1994). After neuronal PrP knockout, total PrP levels are reduced (Mallucci et al., 2003; Mallucci et al., 2002; Mallucci et al., 2007) and neurons no longer propagate prions; glial prion replication taking over. Beyond the reversal of pathology and increased survival in this model, what is striking is that by 48 wpi (weeks post infection) levels of $\mathrm{PrP}^{\mathrm{Sc}}$ and titres of prion infectivity are as high as in the terminally ill wild type controls. The key difference, apart from the localization of the PrPSc to astrocytes, is the rate at which this accumulation occurs. The levels of infectivity and prion replication in control mice rise from basal to end stage in 4 weeks, while in animals with neuronal PrP knockout, the same increase takes 40 weeks. It is therefore also possible that at a lower rate of production, neurons can 'clear' the toxic species, wherever this is produced.

Collinge and colleagues have proposed a model to explain a 'clearance theory' for PrP toxic species, which they term $\operatorname{PrP}^{\mathrm{L}}$ (for PrP 'lethal'). During the conversion of PrPC to $\mathrm{PrPSc}$, the putative neurotoxic intermediate molecule, $\mathrm{PrP}^{\mathrm{L}}$ might be formed (Hill and Collinge, 2003; Collinge and Clarke, 2007). Such an intermediate form of PrP may be different from the infectious form of PrP aggregates, and be rapidly cleared or sequestered into large $\mathrm{PrPSc}^{\mathrm{Sc}}$ aggregates. According to this model, the rate of neurodegeneration would depend on the level of steady state 'PrPL', which could explain the uncoupling of prion titre and neurotoxicity seen in experimental models. Preventing the conversion of $\mathrm{PrP}^{\mathrm{C}}$ into $\mathrm{PrP}^{\mathrm{Sc}}$ should also prevent the generation of ' $\mathrm{PrP}{ }^{\mathrm{L}}$ ', 
whereas targeting $\mathrm{PrP}^{\mathrm{Sc}}$, the end product of the conversion process, might increase the level of ' $\mathrm{PrP} \mathrm{P}^{\mathrm{L}}$. This model is consistent with the data from neuronally PrP-deleted mice, where the knockdown would impact on steady state level of a neurotoxic intermediate.

Further analysis of the Cre-mediated PrP knockout animals certainly supports the generation of a toxic species that is transient and separate to $\mathrm{PrPSc}^{\mathrm{Sc}}$. There are lessons to be learnt specifically from the course of reversal of the early pathology in these mice. Analysis showed that early pathology correlated with early functional deficits that recovered rapidly when PrP was deleted, consistent with transient toxicity. Moreover, the earliest 'toxic' effects were functional, not degenerative, implying a disturbance of neuronal function upstream of neurodegeneration. Thus early spongiform change was associated with cognitive and behavioral deficits and impaired neurophysiological function that recovered post knockout (Mallucci et al., 2007). Coincident with earliest spongiform change, 8 wpi, mice lost the capacity for novel object recognition, a test of non-spatial memory, and showed significantly reduced species- specific burrowing behavior, both of which reflect hippocampal dysfunction. Neurophysiological examination revealed concurrent reduced synaptic responses in CA1 hippocampal neurons. Remarkably, within a week, soon after neuronal PrP depletion both cognitive/behavioral and synaptic deficits recovered and this recovery was sustained up to $30 \mathrm{wpi}$, in parallel with recovery of spongiform change and sustained neuroprotection. Further, the deficits occur before extensive $\mathrm{PrP}^{\mathrm{Sc}}$ deposits accumulate and recover rapidly after $\mathrm{PrP}^{\mathrm{C}}$ depletion, again supporting the concept that they are caused by a transient neurotoxic species, distinct from aggregated PrPSc (Mallucci et al., 2007). The behavioral changes can similarly be prevented by lentivirallymediated knockdown of $\mathrm{PrP}^{\mathrm{C}}$ using RNA interference (White et al., 2008).

Thus this model uncouples prion neurotoxicity and $\mathrm{PrP}^{\mathrm{Sc}}$ and prion titre, strongly supports the generation of a transient toxic intermediate, and overall supports the concept that this generation needs to be intra-neuronal to manifest its neurotoxicity. More recent evidence also implicates the necessity of intra-neuronal, or at least neuronal surface prion replication for neurotoxicity. $\operatorname{PrPC}^{\mathrm{C}}$ (and $\mathrm{PrPSc}^{\mathrm{Sc}}$ ) is attached to the cell surface by a glycosyphosphatidylinositol (GPI) moiety added to its C-terminus during processing in the Golgi, which anchors it to the outer leaflet of the plasma membrane (Caughey et al., 1989; Stahl et al., 1987). PrPC is localised to cholesterol-rich lipid rafts within the plasma membrane, in part mediated by the affinity of the GPI anchor for saturated lipid species (Kaneko et al., 1997; Madore et al., 1999; Taraboulos et al., 1995; Vey et al., 1996), although some studies have shown $\mathrm{PrP}^{\mathrm{C}}$ association with rafts in an independent manner, determined by PrPC's $\mathrm{N}$-terminus (Baron and Caughey, 2003; Campana et al., 2007; Sanghera and Pinheiro, 2002; Walmsley et al., 2003). The function of GPI anchors is poorly understood, and GPI anchored proteins may serve a variety of functions (receptors, adhesion, enzymes, complement regulation, signal transduction). The enrichment of GPI anchors, along with glycosphingolipids and cholesterol, in rafts locates them within these relatively rigid platforms on which, through the interaction of surface and cytoplasmic proteins, several signal transduction pathways are triggered and vesicular trafficking is organized (Fontaine et al., 2003; Mukasa et al., 1995; Oxley and Bacic, 1999). Recent evidence also suggests that GPI-linkage is required for many proteins in order to assume their fully functional conformation (Macrae et al., 2005). GPI-anchorage might also be important for apical targeting of proteins in polarised cells such as those of the intestinal epithelium, which conceivably could apply also to neurons.

The role of the GPI anchor in $\mathrm{PrP}^{\mathrm{C}}$ function is not clear, but is it necessary for the toxicity and replication of prions? In cell-free experiments and in vitro anchorless $\mathrm{PrP}^{\mathrm{C}}$ can be converted to PrPSc (Caughey and Raymond, 1991; Kocisko et al., 1994; Lawson et al., 2001; Rogers et al., 1993). However, others report that removing the anchor from $\mathrm{PrPC}^{\mathrm{C}}$ by treating with phosphatidylinositol-specific phospholipase C (PI-PLC) before exposure to scrapie prevents both infection and propagation in N2a cells (Enari et al., 2001). $\mathrm{PI}-\mathrm{PLC}$ removes the anchor from $\mathrm{PrP}^{\mathrm{C}}$ but not from $\mathrm{PrPSc}$, but cathepsin-D does cleave the GPI moiety from $\mathrm{PrPSc}^{\text {. }}$ Cathespin-D treated RML brain homogenate can infect both N2a cells and wild type mice (Lewis et al., 2006), suggesting that the GPI anchor on PrPSc is not needed for infection.

Chesebro and co-workers generated mice expressing anchorless $\mathrm{PrP}^{\mathrm{C}}$ to address the role of the anchor in prion replication and neurotoxicity in vivo. These animals produced anchorless soluble monomeric $\mathrm{PrP}^{\mathrm{C}}$ (GPI- $\left.\mathrm{PrP}\right)$. In neurons cultured from these mice, GPI- PrP was not detectable on the plasma membrane, instead, around $90 \%$ was secreted into the medium and the rest detected in the ER and Golgi (Campana et al., 2007; Chesebro et al., 2005). Thus $\mathrm{GPI}^{-}$ $\mathrm{PrP}$ is secreted rather than retained intracellulary, indeed intracellular levels of $\mathrm{GPI}^{-} \mathrm{PrP}$ were similar to those in control mice (Chesebro et al., 2005). These animals were essentially healthy and viable, but most significantly, were resistant to prion disease. Animals expressing GPI- PrP did not develop clinical prion disease symptoms when infected with various mouse prion strains (RML, ME7, 22L) up to 400-600 days post infection (dpi), compared to control wild type mice that developed clinical symptoms within 140-160 days, depending on the strain used (Chesebro et al., 2005). Strikingly, however, the animals had widespread amyloid plaques of PrPSc throughout the brain, particularly near blood vessels. Plaques were detected from around $70 \mathrm{dpi}$ and were progressively more widely distributed after 213 dpi. Some animals had up to $40 \%$ more $\mathrm{PrP}^{\mathrm{Sc}}$ than clinically sick infected non-transgenic controls. GPI- PrP expression thus supports prion replication and $\mathrm{PrP}^{\mathrm{Sc}}$ deposition, but not the development of neurotoxicity or clinical disease, reminiscent of neuronal PrP knockout mice (Figure 3). Again there is clear uncoupling of $\mathrm{PrPSc}^{\mathrm{Sc}}$ accumulation and neurotoxicity, and the lack of surface anchoring of $\mathrm{PrPC}^{\mathrm{C}}$ in this model further supports a role for prion neuronal conversion, mediated by $\mathrm{GPI}$-anchored $\mathrm{PrPC}^{\mathrm{C}}$, as central to neurotoxicity. That it is $\mathrm{PrP}^{\mathrm{C}}$, and not $\mathrm{PrPSc}^{\mathrm{S}}$, that must be anchored is confirmed by the fact that blood or brain homogenates from RML infected GPI-negative mice were infectious to wild type mice (Chesebro et al., 2005; Trifilo et al., 2006), but not to other GPI- PrP mice (Chesebro et al., 2005). The findings are consistent also with observations on the infectivity of cathepsin-D treated $\mathrm{PrPSc}^{\mathrm{Sc}}$ (Lewis et al., 2006). Further, replacing the GPI anchor of $\operatorname{PrPC}^{C}$ with its transmembrane domain, removes it from rafts and inhibits its conversion to $\mathrm{PrPSc}^{\mathrm{S}}$ in vitro (Kaneko et al., 1997). 

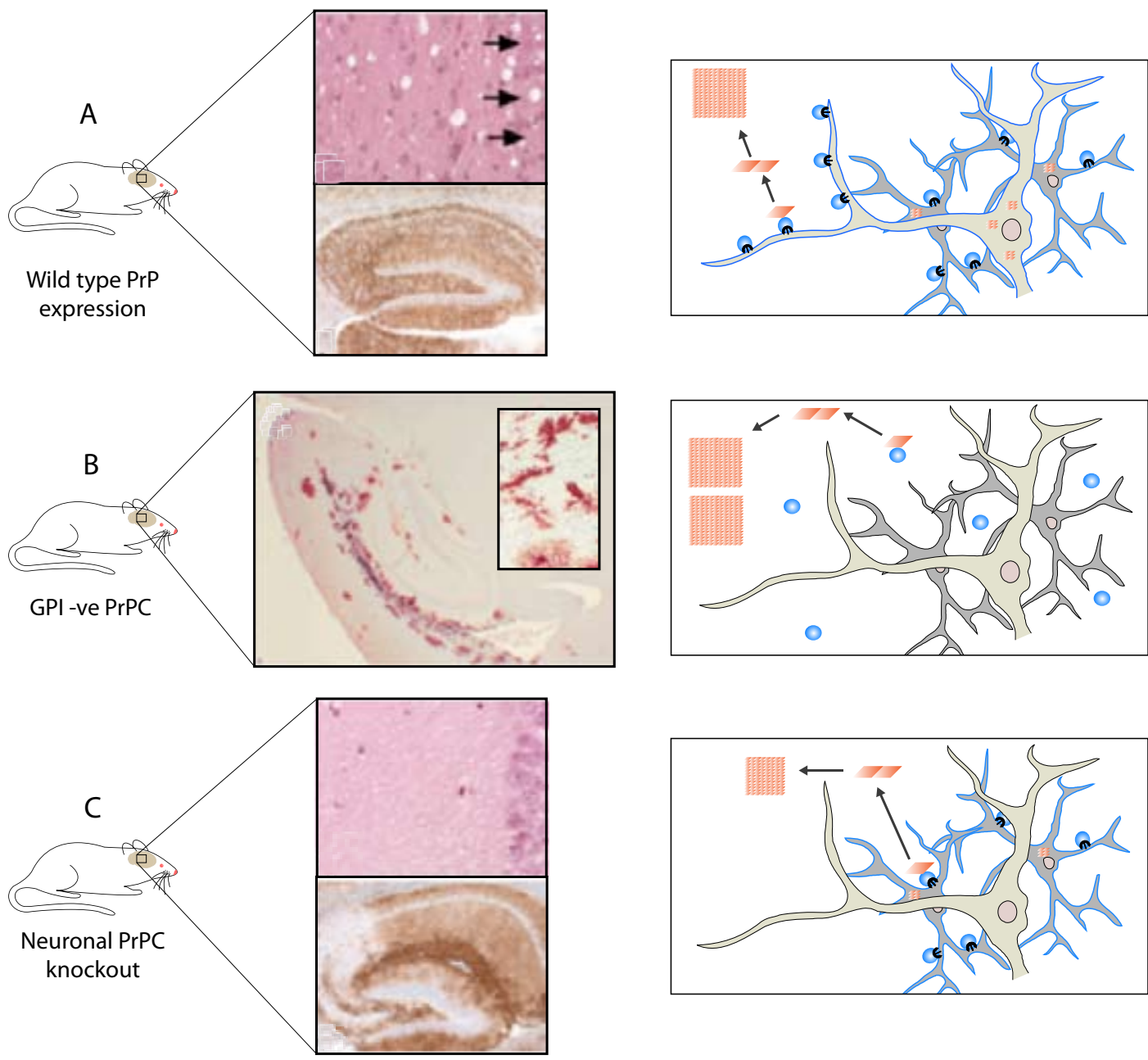

Figure 3. Uncoupling of $\mathrm{PrP}^{\mathrm{Sc}}$ depostion and neurotoxicity in transgenic mice models. A. Mice expressing GPI-anchored PrPC (blue circles = PrPC; GPI anchor in black) physiologically on neurons (pale gray) and astrocytes (darker gray), replicate prions and deposit $\mathrm{PrP}^{\mathrm{Sc}}$, which aggregates (orange squares), causing typical prion neurotoxicity with neuronal loss and spongiosis (upper histology image) and $\mathrm{PrP}^{\mathrm{Sc}}$ depostion (lower immunohistochemistry image). B. Mice expressing anchorless PrPC (blue circles; no anchor) do not have $\mathrm{PrP}^{\mathrm{C}}$ on the neuronal or astrocytic surface but secrete it, where it is converted into $\mathrm{PrPSc}$ and aggregates into amyloid plaques (histology panel). C. Mice with neuronal PrP knockout but expressing GPI-anchored PrPC on astrocytes only generate $\mathrm{PrP}^{\mathrm{Sc}}$ but are resistant to neurotoxicity (top histology panel). All mice generate PrPSc (lower immunohistochemistry panel) but the mice survive despite its accumulation, without neurotoxicity.

This work supports the hypothesis that the surface conversion of $\mathrm{PrP}^{\mathrm{C}}$ to $\mathrm{PrPSc}^{\mathrm{Sc}}$ requires $\mathrm{PrP}^{\mathrm{C}}$, but not $\mathrm{PrPSc}$, to be GPI anchored. As neurons are the target of prion neurotoxicity it would appear that this process must occur on, or within, neurons. The data have been interpreted as reflecting prion neurotoxicity involving some perturbation of the normal function of $\mathrm{PrPC}^{\mathrm{C}}$, possibly mediated through its anchor, in the presence of prion replication (Aguzzi, 2005). However, other interpretations are possible. The GPI- PrP mouse model raises some questions. While they undoubtedly secrete soluble PrP, which is not located on the cell membrane and is involved in prion conversion extraneuronally, these mice have rather low levels of mutant PrP expression. The authors describe levels of mRNA at about $50 \%$ wild type, but levels of actual protein appear lower still (see Chesebro et al; 2005, Figure S2). Gene dosage of PrP is a clear determinant of prion incubation time (Bueler et al., 1994; Manson et al., 1994; Weissmann et al., 1994) and even hemizygosity for wild type PrP leads to at least doubling of incubation time despite accumulating levels of $\mathrm{PrP}^{\mathrm{Sc}}$ and prion titre. The reported survival of the $\mathrm{GPI}^{-} \mathrm{PrP}$ mice is within this range, so is the survival unrelated to the anchoring but dependent on total levels of expression? It is likely that both the levels of PrP expression and the lack of anchor are significant. There is growing evidence in prion infected cell lines, in which protein trafficking has been selectively impaired, that the endosomal recycling compartment is the likely site of prion conversion (Marijanovic et al., 2009). This compartment is also known to be important in the pathway for internalization of GPI anchored proteins (Mayor et al., 1998), again supporting the need for a GPI anchor on PrPC as being central to prion conversion, as anchorless PrPSc is infectious (Chesebro et al., 2005; Lewis et al., 2006). 


\section{Concluding remarks}

The data discussed here unequivocally uncouple neurotoxicity and prion (and $\mathrm{PrP}^{\mathrm{Sc}}$ ) replication in prion disease, a concept described as early as 1994, when the effects of PrP gene dosage on incubation times were first described (Bueler et al., 1994; Weissmann et al., 1994). They also increasingly provide support for intraneuronal generation of a toxic intermediate, where GPIanchored $\mathrm{PrPC}$ likely plays a crucial role. There are still many unanswered questions, not least what the neurotoxic species is and how, exactly, it causes neuronal dysfunction, and eventually death. The role of pharmacokinetic factors in clearing, depositing and aggregating $\mathrm{PrPSc}^{\mathrm{Sc}}$ and its isoforms further complicates the interpretation of mechanisms of neurotoxicity in these disorders, but clearly is essential to an understanding of the real picture. Targeting the substrate of conversion, $\mathrm{PrP}^{\mathrm{C}}$, remains a therapeutically sound strategy, and new approaches may eventually provide clarity on the details of the toxic culprit and how it acts.

\section{References}

Aguzzi, A. (2005). Cell biology. Prion toxicity: all sail and no anchor. Science 308, 1420- 1421.

Baron, G.S., and Caughey, B. (2003). Effect of glycosylphosphatidylinositol anchor-dependent and -independent prion protein association with model raft membranes on conversion to the protease-resistant isoform. J Biol Chem 278, 14883-14892.

Brandner, S., Isenmann, S., Raeber, A., Fischer, M., Sailer, A., Kobayashi, Y., Marino, S., Weissmann, C., and Aguzzi, A. (1996). Normal host prion protein necessary for scrapie-induced neurotoxicity. Nature 379, 339-343.

Bueler, H., Aguzzi, A., Sailer, A., Greiner, R.A., Autenried, P., Aguet, M., and Weissmann, C. (1993). Mice devoid of PrP are resistant to scrapie. Cell 73, 1339-1347.

Bueler, H., Raeber, A., Sailer, A., Fischer, M., Aguzzi, A., and Weissmann, C. (1994). High prion and PrPSc levels but delayed onset of disease in scrapie-inoculated mice heterozygous for a disrupted PrP gene. Mol Med 1, 19-30.

Campana, V., Caputo, A., Sarnataro, D., Paladino, S., Tivodar, S., and Zurzolo, C. (2007). Characterization of the properties and trafficking of an anchorless form of the prion protein. J Biol Chem 282, 22747-22756.

Caughey, B., Race, R.E., Ernst, D., Buchmeier, M.J., and Chesebro, B. (1989). Prion protein biosynthesis in scrapie-infected and uninfected neuroblastoma cells. J Virol 63, 175-181.

Caughey, B., and Raymond, G.J. (1991). The scrapieassociated form of PrP is made from a cell surface precursor that is both protease- and phospholipasesensitive. J Biol Chem 266, 18217-18223.

Chesebro, B., Trifilo, M., Race, R., Meade-White, K., Teng, C., LaCasse, R., Raymond, L., Favara, C., Baron, G., Priola, S., et al. (2005). Anchorless prion protein results in infectious amyloid disease without clinical scrapie. Science 308, 1435-1439.

Collinge, J., Palmer, M.S., Sidle, K.C., Gowland, I., Medori, R., Ironside, J., and Lantos, P. (1995). Transmission of fatal familial insomnia to laboratory animals. Lancet 346 , 569-570.

Collinge, J ., and Clarke, A. (2007). A general model of prion strains and their pathogenicity. Science 318, 930-936.
Diedrich, J.F., Bendheim, P.E., Kim, Y.S., Carp, R.I., and Haase, A.T. (1991). Scrapie-associated prion protein accumulates in astrocytes during scrapie infection. Proc Natl Acad Sci USA 88, 375-379.

Enari, M., Flechsig, E., and Weissmann, C. (2001). scrapie prion protein accumulation by scrapie-infected neuroblastoma cells abrogated by exposure to a prion protein antibody. Proc Natl Acad Sci USA 98, 9295-9299.

Fontaine, T., Magnin, T., Melhert, A., Lamont, D., Latge, J.P., and Ferguson, M.A. (2003). Structures of the glycosylphosphatidylinositol membrane anchors from Aspergillus fumigatus membrane proteins. Glycobiology 13, 169-177.

Forloni, G., Angeretti, N., Chiesa, R., Monzani, E., Salmona, M., Bugiani, O., and Tagliavini, F. (1993). Neurotoxicity of a prion protein fragment. Nature $362,543-546$.

Ganat, Y.M., Silbereis, J., Cave, C., Ngu, H., Anderson, G.M., Ohkubo, Y., Ment, L.R., and Vaccarino, F.M. (2006). Early postnatal astroglial cells produce multilineage precursors and neural stem cells in vivo. J Neurosci 26, 8609-8621.

Griffith, J.S. (1967). Self-replication and scrapie. Nature 215, 1043-1044.

Hegde, R.S., Mastrianni, J.A., Scott, M.R., DeFea, K.A., Tremblay, P., Torchia, M., DeArmond, S.J., Prusiner, S.B., and Lingappa, V.R. (1998). A transmembrane form of the prion protein in neurodegenerative disease. Science 279 , 827-834.

Hegde, R.S., and Rane, N.S. (2003). Prion protein trafficking and the development of neurodegeneration. Trends Neurosci 26, 337-339.

Hill, A.F., and Collinge, J. (2003). Subclinical prion infection. Trends Microbiol 11, 578- 584.

Hill, A.F., Joiner, S., Linehan, J., Desbruslais, M., Lantos, P.L., and Collinge, J. (2000). Species-barrier-independent prion replication in apparently resistant species. Proc Natl Acad Sci USA 97, 10248-10253.

Hsiao, K.K., Scott, M., Foster, D., Groth, D.F., DeArmond, S.J., and Prusiner, S.B. (1990). Spontaneous neurodegeneration in transgenic mice with mutant prion protein. Science 250, 1587-1590.

Jackson, G.S., Hosszu, L.L., Power, A., Hill, A.F., Kenney, J., Saibil, H., Craven, C.J., Waltho, J.P., Clarke, A.R., and Collinge, J. (1999). Reversible conversion of monomeric human prion protein between native and fibrilogenic conformations. Science 283, 1935- 1937.

Jeffrey, M., Goodsir, C.M., Race, R.E., and Chesebro, B. (2004). Scrapie-specific neuronal lesions are independent of neuronal PrP expression. Ann Neurol 55, 781-792.

Kaneko, K., Vey, M., Scott, M., Pilkuhn, S., Cohen, F.E., and Prusiner, S.B. (1997). COOH-terminal sequence of the cellular prion protein directs subcellular trafficking and controls conversion into the scrapie isoform. Proc Natl Acad Sci USA 94, 2333-2338.

Kocisko, D.A., Come, J.H., Priola, S.A., Chesebro, B., Raymond, G.J., Lansbury, P.T., and Caughey, B. (1994). Cell-free formation of protease-resistant prion protein. Nature 370, 471-474.

Lawson, V.A., Priola, S.A., Wehrly, K., and Chesebro, B. (2001). N-terminal truncation of prion protein affects both formation and conformation of abnormal proteaseresistant prion protein generated in vitro. J Biol Chem 276, 35265-35271. 
Lewis, P.A., Properzi, F., Prodromidou, K., Clarke, A.R., Collinge, J., and Jackson, G.S. (2006). Removal of the glycosylphosphatidylinositol anchor from $\operatorname{PrP}(\mathrm{sc})$ by cathepsin $D$ does not reduce prion infectivity. Biochem $J$ 395, 443-448.

Ma, J., and Lindquist, S. (2002). Conversion of PrP to a self-perpetuating $\mathrm{PrP}^{\mathrm{Sc}}$-like conformation in the cytosol. Science 298, 1785-1788.

Macrae, J.I., Acosta-Serrano, A., Morrice, N.A., Mehlert, A., and Ferguson, M.A. (2005). Structural characterization of NETNES, a novel glycoconjugate in Trypanosoma cruzi epimastigotes. J Biol Chem 280, 12201-12211.

Madore, N., Smith, K.L., Graham, C.H., Jen, A., Brady, K., Hall, S., and Morris, R. (1999). Functionally different GPI proteins are organized in different domains on the neuronal surface. EMBO J 18, 6917-6926.

Mallucci, G., and Collinge, J. (2005). Rational targeting for prion therapeutics. Nat Rev Neurosci 6, 23-34.

Mallucci, G., Dickinson, A., Linehan, J., Klohn, P.C., Brandner, S., and Collinge, J. (2003). Depleting neuronal $\mathrm{PrP}$ in prion infection prevents disease and reverses spongiosis. Science 302, 871-874.

Mallucci, G.R., Ratte, S., Asante, E.A., Linehan, J., Gowland, I., Jefferys, J.G., and Collinge, J. (2002). Postnatal knockout of prion protein alters hippocampal CA1 properties, but does not result in neurodegeneration. EMBO J 21, 202-210.

Mallucci, G.R., White, M.D., Farmer, M., Dickinson, A., Khatun, H., Powell, A.D., Brandner, S., Jefferys, J.G., and Collinge, J. (2007). Targeting cellular prion protein reverses early cognitive deficits and neurophysiological dysfunction in prion-infected mice. Neuron 53, 325-335.

Manson, J.C., Clarke, A.R., McBride, P.A., McConnell, I., and Hope, J. (1994). PrP gene dosage determines the timing but not the final intensity or distribution of lesions in scrapie pathology. Neurodegeneration 3, 331-340.

Marijanovic, Z., Caputo, A., Campana, V., and Zurzolo, C. (2009). Identification of an intracellular site of prion conversion. PLoS Pathog 5, e1000426.

Mayor, S., Sabharanjak, S., and Maxfield, F.R. (1998). Cholesterol-dependent retention of GPI-anchored proteins in endosomes. EMBO J 17, 4626-4638.

Medori, R., Montagna, P., Tritschler, H.J., LeBlanc, A., Cortelli, P., Tinuper, P., Lugaresi, E., and Gambetti, P. (1992). Fatal familial insomnia: a second kindred with mutation of prion protein gene at codon 178. Neurology 42, 669-670.

Morshead, C.M., Garcia, A.D., Sofroniew, M.V., and van Der Kooy, D. (2003). The ablation of glial fibrillary acidic protein-positive cells from the adult central nervous system results in the loss of forebrain neural stem cells but not retinal stem cells. Eur J Neurosci 18, 76-84.

Mukasa, R., Umeda, M., Endo, T., Kobata, A., and Inoue, K. (1995). Characterization of glycosylphosphatidylinositol (GPI)-anchored NCAM on mouse skeletal muscle cell line $\mathrm{C} 2 \mathrm{C} 12$ : the structure of the GPI glycan and release during myogenesis. Arch Biochem Biophys 318, 182-190.

Muller, W.E., Ushijima, H., Schroder, H.C., Forrest, J.M., Schatton, W.F., Rytik, P.G., and Heffner-Lauc, M. (1993). Cytoprotective effect of NMDA receptor antagonists on prion protein (PrionSc)-induced toxicity in rat cortical cell cultures. Eur J Pharmacol 246, 261-267.
Oxley, D., and Bacic, A. (1999). Structure of the glycosylphosphatidylinositol anchor of an arabinogalactan protein from Pyrus communis suspension-cultured cells. Proc Natl Acad Sci USA 96, 14246-14251.

Prusiner, S.B. (1982). Novel proteinaceous infectious particles cause scrapie. Science 216, 136-144.

Prusiner, S.B. (1991). Molecular biology of prion diseases. Science 252, 1515-1522.

Race, R., Raines, A., Raymond, G.J., Caughey, B., and Chesebro, B. (2001). Long-term subclinical carrier state precedes scrapie replication and adaptation in a resistant species: analogies to bovine spongiform encephalopathy and variant Creutzfeldt-Jakob disease in humans. J Virol 75, 10106-10112.

Race, R.E., Priola, S.A., Bessen, R.A., Ernst, D., Dockter, J., Rall, G.F., Mucke, L., Chesebro, B., and Oldstone, M.B. (1995). Neuron-specific expression of a hamster prion protein minigene in transgenic mice induces susceptibility to hamster scrapie agent. Neuron 15, 1183-1191.

Raeber, A.J., Race, R.E., Brandner, S., Priola, S.A., Sailer, A., Bessen, R.A., Mucke, L., Manson, J., Aguzzi, A., Oldstone, M.B., et al. (1997). Astrocyte-specific expression of hamster prion protein (PrP) renders PrP knockout mice susceptible to hamster scrapie. EMBO J 16, 6057-6065.

Rogers, M., Yehiely, F., Scott, M., and Prusiner, S.B. (1993). Conversion of truncated and elongated prion proteins into the scrapie isoform in cultured cells. Proc Natl Acad Sci USA 90, 3182-3186.

Sailer, A., Bueler, H., Fischer, M., Aguzzi, A., and Weissmann, C. (1994). No propagation of prions in mice devoid of PrP. Cell 77, 967-968.

Sanghera, N., and Pinheiro, T.J. (2002). Binding of prion protein to lipid membranes and implications for prion conversion. J Mol Biol 315, 1241-1256.

Silbereis, J., Cheng, E., Ganat, Y.M., Ment, L.R., and Vaccarino, F.M. (2009). Precursors with glial fibrillary acidic protein promoter activity transiently generate GABA interneurons in the postnatal cerebellum. Stem Cells 27, 1152-1163.

Stahl, N., Borchelt, D.R., Hsiao, K., and Prusiner, S.B. (1987). scrapie prion protein contains a phosphatidylinositol glycolipid. Cell 51, 229-240.

Taraboulos, A., Scott, M., Semenov, A., Avrahami, D., Laszlo, L., and Prusiner, S.B. (1995). Cholesterol depletion and modification of $\mathrm{COOH}$-terminal targeting sequence of the prion protein inhibit formation of the scrapie isoform. $J$ Cell Biol 129, 121-132.

Tateishi, J., Kitamoto, T., Doh-ura, K., Boellaard, J.W., and Peiffer, J. (1992). Creutzfeldt-Jakob disease with amyloid angiopathy: diagnosis by immunological analyses and transmission experiments. Acta Neuropathol 83, 559-563.

Trevitt, C.R., and Collinge, J. (2006). A systematic review of prion therapeutics in experimental models. Brain 129, 2241-2265.

Trifilo, M.J., Yajima, T., Gu, Y., Dalton, N., Peterson, K.L., Race, R.E., Meade-White, K., Portis, J.L., Masliah, E., Knowlton, K.U., et al. (2006). Prion-induced amyloid heart disease with high blood infectivity in transgenic mice. Science 313, 94-97.

Vey, M., Pilkuhn, S., Wille, H., Nixon, R., DeArmond, S.J., Smart, E.J., Anderson, R.G., Taraboulos, A., and Prusiner, S.B. (1996). Subcellular colocalization of the cellular and 
scrapie prion proteins in caveolae-like membranous domains. Proc Natl Acad Sci USA 93, 14945-14949.

Walmsley, A.R., Zeng, F., and Hooper, N.M. (2003). The $\mathrm{N}$-terminal region of the prion protein ectodomain contains a lipid raft targeting determinant. J Biol Chem 278, 3724137248.

Weissmann, C., Bueler, H., Fischer, M., Sauer, A., and Aguet, M. (1994). Susceptibility to scrapie in mice is dependent on PrPC. Philos Trans R Soc Lond B Biol sci 343, 431- 433.

White, M.D., Farmer, M., Mirabile, I., Brandner, S., Collinge, J., and Mallucci, G.R. (2008). Single treatment with RNAi against prion protein rescues early neuronal dysfunction and prolongs survival in mice with prion disease. Proc Natl Acad Sci USA 105, 10238-10243. 


\section{Further Reading}

Caister Academic Press is a leading academic publisher of advanced texts in microbiology, molecular biology and medical research. Full details of all our publications at caister.com

- MALDI-TOF Mass Spectrometry in Microbiology Edited by: M Kostrzewa, S Schubert (2016) www.caister.com/malditof

- Aspergillus and Penicillium in the Post-genomic Era Edited by: RP Vries, IB Gelber, MR Andersen (2016) www.caister.com/aspergillus2

- The Bacteriocins: Current Knowledge and Future Prospects Edited by: RL Dorit, SM Roy, MA Riley (2016)

www.caister.com/bacteriocins

- Omics in Plant Disease Resistance Edited by: V Bhadauria (2016) www.caister.com/opd

- Acidophiles: Life in Extremely Acidic Environments Edited by: R Quatrini, DB Johnson (2016) www.caister.com/acidophiles

- Climate Change and Microbial Ecology: Current Research and Future Trend

Edited by: J Marxsen (2016)

www.caister.com/climate

- Biofilms in Bioremediation: Current Research and Emerging Technologies

Edited by: G Lear (2016)

www.caister.com/biorem

- Microalgae: Current Research and Applications Edited by: MN Tsaloglou (2016) www.caister.com/microalgae

- Gas Plasma Sterilization in Microbiology: Theory, Applications, Pitfalls and New Perspectives Edited by: H Shintani, A Sakudo (2016) www.caister.com/gasplasma

- Virus Evolution: Current Research and Future Directions Edited by: SC Weaver, M Denison, M Roossinck, et al. (2016) www.caister.com/virusevol

- Arboviruses: Molecular Biology, Evolution and Control Edited by: N Vasilakis, DJ Gubler (2016) www.caister.com/arbo

- Shigella: Molecular and Cellular Biology Edited by: WD Picking, WL Picking (2016) www.caister.com/shigella

-Aquatic Biofilms: Ecology, Water Quality and Wastewater Treatment

Edited by: AM Romaní, H Guasch, MD Balaguer (2016)

www.caister.com/aquaticbiofilms

- Alphaviruses: Current Biology

Edited by: S Mahalingam, L Herrero, B Herring (2016)

www.caister.com/alpha

- Thermophilic Microorganisms

Edited by: F Li (2015)

www.caister.com/thermophile
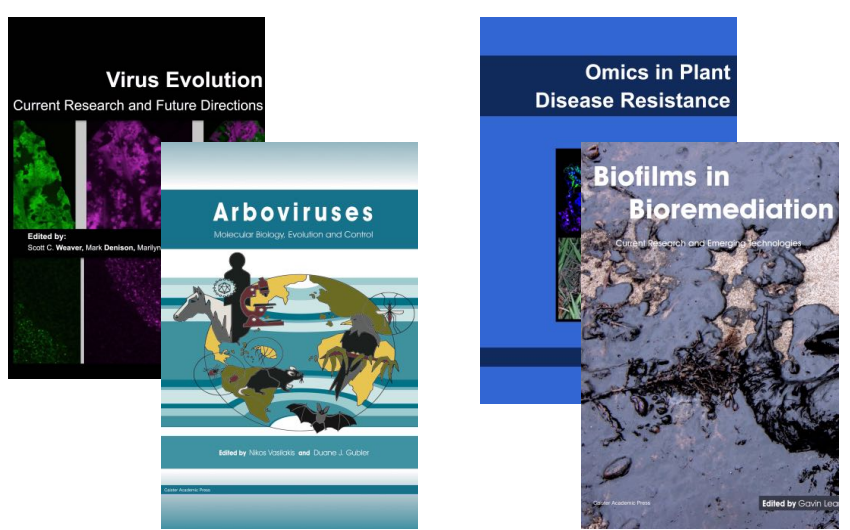
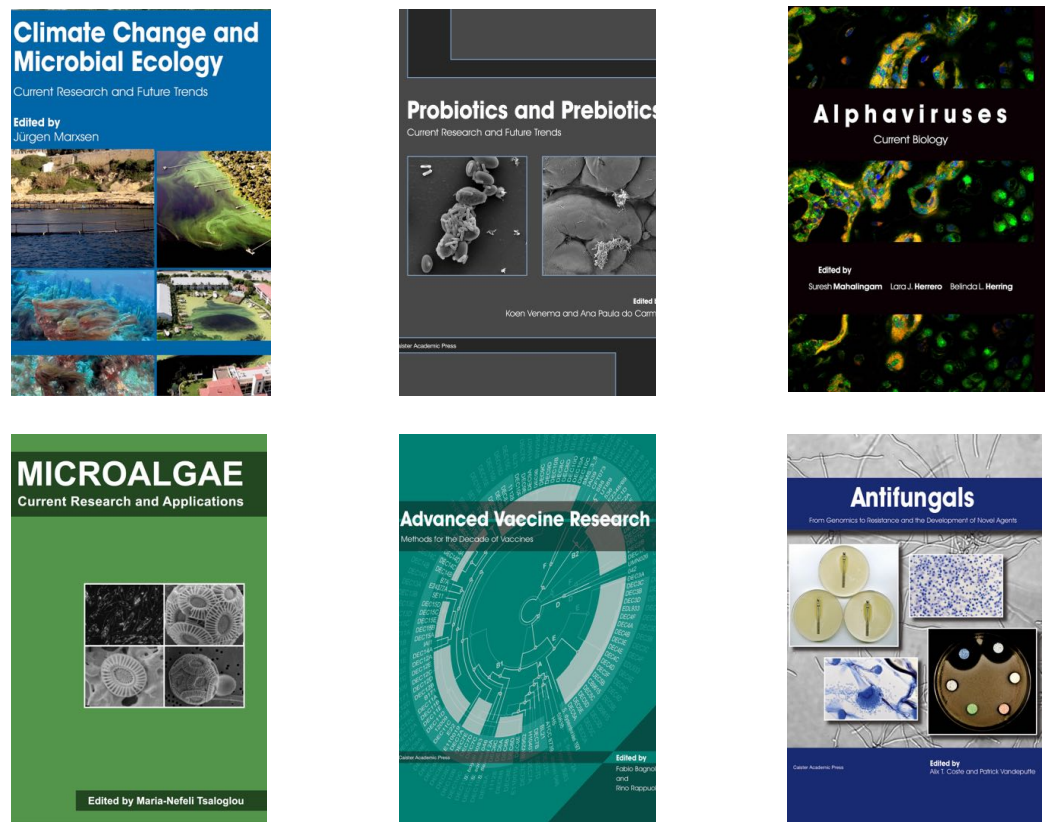

- Flow Cytometry in Microbiology: Technology and Applications Edited by: MG Wilkinson (2015) www.caister.com/flow

- Probiotics and Prebiotics: Current Research and Future Trends Edited by: K Venema, AP Carmo (2015) www.caister.com/probiotics

- Epigenetics: Current Research and Emerging Trends Edited by: BP Chadwick (2015) www.caister.com/epigenetics2015

- Corynebacterium glutamicum: From Systems Biology to Biotechnological Applications

Edited by: A Burkovski (2015)

www.caister.com/cory2

- Advanced Vaccine Research Methods for the Decade of Vaccines

Edited by: F Bagnoli, R Rappuoli (2015)

www.caister.com/vaccines

- Antifungals: From Genomics to Resistance and the Development of Novel Agents

Edited by: AT Coste, P Vandeputte (2015)

www.caister.com/antifungals

- Bacteria-Plant Interactions: Advanced Research and Future Trends Edited by: J Murillo, BA Vinatzer, RW Jackson, et al. (2015) www.caister.com/bacteria-plant

\section{- Aeromonas}

Edited by: J Graf (2015)

www.caister.com/aeromonas

- Antibiotics: Current Innovations and Future Trends

Edited by: S Sánchez, AL Demain (2015)

www.caister.com/antibiotics

- Leishmania: Current Biology and Contro Edited by: S Adak, R Datta (2015) www.caister.com/leish2

- Acanthamoeba: Biology and Pathogenesis (2nd edition) Author: NA Khan (2015)

www.caister.com/acanthamoeba2

- Microarrays: Current Technology, Innovations and Applications Edited by: Z He (2014)

www.caister.com/microarrays2

- Metagenomics of the Microbial Nitrogen Cycle: Theory, Methods and Applications

Edited by: D Marco (2014)

www.caister.com/n2 